УДК 347.122

DOI https://doi.org/10.32849/2663-5313/2020.5.06

\author{
Андрій Потапенко, \\ суддя Ржищевського міського суду Київської області, \\ аспірант відділу юрисдикиійних форм правового захисту \\ суб'єктів приватного права, судоустрою та судочинства \\ Науково-дослідного інституту приватного права і підприємничтва \\ імені академіка Ф.Г. Бурчака \\ Начіональної академії правових наук України
}

\title{
ВИМОГА ЕФЕКТИВНОГО ЗАХИСТУ ПРАВА У ПРОЦЕСУАЛЬНИХ ДОКУМЕНТАХ: ПОГЛЯД 3 ПОЗИЦІЇ СТОРІН ЦИВІЛЬНОГО ПРОЦЕСУ
}

Стаття присвячена дослідженню та аналізу вимоги ефективного захисту приватного права та інтересу у прочесуальних документах з позииї сторін иивільного процесу як новели иивільного процесуального законодавства. Доведено, що задля запобігання неоднаковому тлумаченню закону, прогнозування можливих помилок у застосуванні сторонами иивільного проиесу та судами існує наукова та практична необхідність вироблення єдиних підходів до формування вимоги ефективного захисту права у прочесуальних документах. Обгрунтовано з позииії прав та обов'язків сторін иивільного процесу окремі підстави формування вимоги ефективного захисту права у процесуальних документах як обов'язкових задля правильного визначення судом ефективного способу захисту, який не суперечить закону; підстави сформовано на основі наявних наукових близьких за предметом регулювання правових категорій щодо досліджуваної новели, а також в основі аналізу практики національних судів. Доведено, що вимога про застосування судом ефективного способу захисту порушеного, невизнаного або оспореного приватного права та інтересу, який не суперечить закону, має бути викладена у позовній заяві, а саме має бути відображена у змісті позовних вимог. Обгрунтовано, що визначення предмета та підстави позову є виключним вольовим правом позивача, суд позбавлений права на відповідну прощесуальну ініщіативу. Доведено, що суд за приниипом јита потіt ситіа самостійно здійснює правову кваліфікаиію спірних правовідносин та застосовує для прийняття рішення саме ті норми матеріального права, предметом регулювання яких є відповідні правовідносини, що не приводить до зміни предмета позову та/або вибраного позивачем способу захисту. Сформовано науково обгрунтовані підстави формування вимоги ефективного захисту приватного права та інтересу, що є обов'язковими в аспекті застосування новели «визначення судом ефективного способу захисту порушеного, невизнаного або оспореного приватного права та інтересу» складають основоположні засади застосування новели, тому мають враховуватися сторонами цивільного процесу та судом під час складання процесуальних документів у цивільному процесі.

Ключові слова: вимога ефективного захисту порушеного, невизнаного або оспорюваного права, визначення судом ефективного способу захисту, спосіб захисту, який не суперечить закону, ефективний засіб юридичного захисту, процесуальна ініціатива.

Постановка проблеми. Відомий суддя, вчений Аарон Барак, визначаючи формальні джерела суддівського розсуду, зазначав, що суддя не може вирішити справу, поки не буде мати перед собою правову норму, відповідно до якої справа буде вирішуватися. Влада вирішувати спір тягне як природний результат владу визначати правову норму, відповідно до якої справа буде вирішуватися, а також іï межі застосування. Це визначення здійснюється для сторін, однак з огляду на принцип зобов'язального прецеденту йому надається загальна нормативна сила у справах, у яких воно застосовується. Рішення стає актом правотворчості [1, с. 129].
Надання суду елементів правотворчості, створення нових, ефективних засобів юридичного захисту для реалізації основного завдання здійснення ефективного цивільного судочинства слугували, на нашу думку, аргументами законодавця задля запровадження у Законі України від 3 жовтня 2017 року № 2147-VIII новели цивільного процесуального законодавства, а саме права суду на підставі викладеної у позові вимоги визначити ефективний спосіб захисту порушеного, невизнаного або оспореного приватного права та інтересу, який не суперечить закону (далі - новели) [2].

Водночас слід провести наукове дослідження підстав формування вимоги 
ефективного захисту права в процесуальних документах як обов'язкових, що $є$ необхідним задля правильного застосування нового процесуального засобу, а саме визначення судом відповідно до викладеної в позові вимоги ефективного способу захисту, який не суперечить закону.

Окремі питання правового регулювання відносин захисту суб'єктивних цивільних прав, зокрема в аспекті ефективності судового захисту, належності вибору судових способів досліджувались у працях таких науковців, як С.С. Алексєєв, О.А. Беляневич, Т.В. Боднар, І.В. Венедиктова, М.К. Галянтич, О.В. Дзера, О.О. Кот, О.В. Кохановська, О.Д. Крупчан, Н.С. Кузнєцова, В.В. Луць, Р.А. Майданик, Т.М. Підлубна, С.О. Погрібний, Ю.Д. Притика, Я.М. Романюк, О.М. Сасевич, І.В. Спасибо-Фатєєва, Р.О. Стефанчук, А.Г. Ярема, Т.М. Ярова, В.Л. Яроцький.

Водночас у доктрині цивільного процесуального права України не здійснювалось фундаментальних теоретичних напрацювань щодо вимоги ефективного захисту приватного права та інтересу, сформованих у процесуальних документах з позиції сторін цивільного процесу, межі повноважень суду щодо вирішення такої вимоги, а також правової природи ефективного способу судового захисту порушеного, невизнаного або оспореного приватного права як вимоги, викладеної у процесуальних документах.

Метою статті $\epsilon$ розкриття теоретичних і практичних засад формування вимоги ефективного захисту у процесуальних документа щодо позиції сторін цивільного процесу як нового процесуального інструменту, відпрацювання на цій основі висновків, узагальнень, практичних пропозицій і конкретних рекомендацій, спрямованих на ефективне запровадження новели.

Виклад основного матеріалу. Задля запобігання неоднаковому тлумаченню закону, прогнозування можливих помилок у застосуванні судами новели або навіть усунення можливих зловживань як сторонами у справах, так і судом, на нашу думку, слід застосовувати єдині підходи до формування вимоги ефективного способу захисту приватного права та інтересу.

3 огляду на тлумачення положень новели цивільного процесуального права, передбаченої ч. 2 ст. 5 ЦПК України окремо та у ï взаємозв'язку з іншими положеннями цивільного процесуального законодавства, спираючись на релевантну судову практику застосування новели, запропонуємо такі підстави визначення вимоги ефективного способу захисту порушеного, невизнаного або оспореного приватного права та інтересу шляхом групування їх за певними авторськими критеріями.

1) Викладення у позовній заяві вимоги про застосування судом ефективного способу захисту порушеного, невизнаного або оспореного приватного права та інтересу, який не суперечить закону.

Першою та найтиповішою помилкою тлумачення та застосування новели є твердження про те, що суд вправі визначити у судовому рішенні ефективний спосіб захисту порушеного, невизнаного або оспореного приватного права та інтересу навіть за умови відсутності такої вимоги (конкретно сформульованого способу захисту) у позовній заяві. До такого ж самого помилкового висновку дійшов автор статті під час первинного аналізу новели, що була передбачена у проєкті відповідного закону. Такому хибному висновку сприяла не зовсім вдала, на наш погляд, редакція норми ч. 2 ст. 5 ЦПК України: суд, «відповідно викладеної в позові вимоги» такої особи, може визначити у своєму рішенні такий спосіб захисту, який не суперечить закону, якщо закон або договір не визначають ефективного способу захисту порушеного, невизнаного або оспореного права, свободи чи інтересу особи, яка звернулася до суду [2]. Буквальне тлумачення новели дало змогу правникам дійти висновків на користь того, що суд нібито вправі самостійно визначити ефективний спосіб захисту, вийшовши поза межі позовних вимог. Наведене законодавче формулювання щодо форми позовної вимоги потребувало додаткового пояснення, яким же саме чином має діяти суд, коли він визначає ефективний спосіб захисту «відповідно викладеної в позові вимоги». Насправді в основі цієї дискусії лежить сутність природно-правової концепції новели, яка визначає шлях подальшого розвитку засобів ефективного захисту прав та інтересів у цивільному судочинстві. Цей шлях можна спрямувати у напрямі «повної» чи «безмежної» судової дискреції під час визначення ефективного способу захисту з наданням переваги модним «європейським» трендам ефективного захисту приватного права людини, або надати новелі та ролі суду у його «судовій дискреції» під час її застосування форми збалансованого процесуального інструменту, що буде одночасно дієвим та таким, що відповідає усім вимогам принципів цивільного судочинства.

На думку М.В. Уса, для досягнення мети цивільного судочинства, яка в ч. 1 ст. 2 ЦПК визначена як ефективний захист прав (інтересів), судам слід займати активну позицію у коригуванні вимоги позивача, а саме зазна- 
чати в рішенні ефективний спосіб захисту, змінюючи за необхідності вибрану позивачем вимогу (наприклад, «визнання торгів незаконними» замінити на «визнання торгів недійсними»), проте на це має бути згода позивача з огляду на принципи диспозитивності, хоча чіткої вимоги щодо отримання такої згоди процесуальний кодекс не містить. Також відсутня судова практика, яка б давала відповідь на питання про те, на якій стадії судового розгляду і в якій формі має отримуватися відповідна згода. Водночас таке втручання суду не має йти в розріз із засадами диспозитивності, змагальності цивілістичного процесу: усуваючи помилки, неточності чи прогалини, допущені позивачем під час формулювання способу захисту, суд ризикує поставити позивача в переважне становище, що є неприпустимим [3].

Розвиваючі підняті вище питання, вважаємо, що допустимою поведінкою суду щодо усунення неточностей чи прогалин, допущених позивачем під час формулювання ефективного способу захисту, будуть виконання повноважень суду щодо роз'яснення учасникам судового процесу їхніх процесуальних прав та обов'язків, наслідків вчинення або невчинення процесуальних дій та сприяння учасникам судового процесу в реалізації ними прав (ч. 5 ст. 12 ЦПК України). Ці дії будуть прийнятними, коли суд буде діяти, зберігаючи об'єктивність і неупередженість. Зазначені процесуальні дії слід провести у підготовчому провадженні під час стадії остаточного визначення предмета спору та характеру спірних правовідносин, позовних вимог (п. 1 ч. 1 ст. 189 ЦПК України).

Однак сьогодні здебільшого переважає така теза. Поглиблений аналіз новели, на нашу думку, свідчить про те, що вимога про застосування судом ефективного способу захисту порушеного, невизнаного або оспореного приватного права та інтересу (який не суперечить закону) має бути викладена у позовній заяві, а саме бути конкретно сформульована як матеріально-правовий захід примусового характеру й не бути абстрактною.

Беззаперечним аргументом на користь такого підходу є законодавче закріплення вимог щодо позовної заяви, а саме у змісті позовних вимог. Пунктом 4 ч. 3 ст. 175 ЦПК України передбачено, що позовна заява повинна містити зміст позовних вимог, а саме спосіб (способи) захисту прав або інтересів, передбачений законом чи договором, або інший спосіб (способи) захисту прав та інтересів, який не суперечить закону і який позивач просить суд визначити у рішенні [2].

У цьому разі суд буде діяти на засадах принципу диспозитивності, тобто розгля- дати справу не інакше як за зверненням особи, поданим відповідно до цього Кодексу, в межах заявлених нею вимог і на підставі доказів, поданих учасниками справи або витребуваних судом у передбачених цим Кодексом випадках (ч. 1 ст. 13 ЦПК України). Крім того, суд буде обмежений правилом діяти в межах позовних вимог (ч. 2 ст. 264 ЦПК України) [2].

Показовою щодо відсутності викладеної у позові вимоги про застосування ефективного способу захисту порушеного приватного права, який би міг реально поновити трудові права позивача, можна назвати цивільну справу № 759/19440/15-ц, яка розглядалась судами на підставі процесуального законодавства ще до початку дії новели, а саме до 15 грудня 2017 року. У цій справі позивачка не досягла бажаного результату й судового захисту своїх прав, хоча мала б таку можливість в рамках розгляду одного судового провадження за умови дії новели на час звернення до суду, тобто, не захистивши право на працю, позивачка втратила час, ресурси, понесла втрати майнового та немайнового характеру. Водночас суд у цій справі не виконав свого основного завдання здійснити справедливий, неупереджений та своєчасний розгляд і вирішення цивільних справ.

Так, у грудні 2015 року позивачка звернулася до суду з позовом про поновлення на роботі, мотивуючи тим, що відповідач не видав наказ про надання їй відпустки по вагітності та пологах, не здійснив виплат на підставі листка непрацездатності, а 31 серпня 2015 року звільнив іiі із займаної посади на підставі п. 2 ч. 1 ст. 36 КЗпП України у зв'язку із закінченням строку дії контракту. Велика Палата Верховного Суду у Постанові від 16 травня 2018 року зробила правовий висновок, що звільнення жінок, зазначених у ч. 3 ст. 184 КЗпП України, у зв'язку із закінченням строку трудового договору має свої особливості, а саме звільнення, зокрема, вагітних жінок можливе на підставі п. 2 ст. 36 КЗпП України, однак провадиться з обов'язковим працевлаштуванням вагітної, тобто власник зобов'язаний працевлаштувати жінку на цьому ж або іншому підприємстві відповідно до їі фаху. Розрив у часі між звільненням і працевлаштуванням у цьому випадку не допускається [4].

Невиконання підприємством, яке звільнило вагітну жінку, обов'язку щодо працевлаштування є підставою для покладення на нього, відповідно до ч. 2 ст. 232 КЗпП України, обов'язку надати на цьому або іншому підприємстві роботу, яку може виконувати працівниця, виплати їй середньої заробітної плати на період працевлаштування, але не більше трьох 
місяців з дня закінчення строкового трудового договору, а не про поновлення на попередній роботі. Водночас позовних вимог про виконання відповідачем зобов'язання щодо працевлаштування позивачка не заявляла, однак не позбавлена такої можливості [4].

У цій справі Велика Палата Верховного Суду фактично відмовила у судовому захисті приватного права через невідповідність закону заявленої позивачкою вимоги, однак у власних висновках визначила право позивачки сформулювати в новій позовній заяві спосіб захисту, який міг би бути захищений судом у конкретних спірних правовідносинах. Вимога про виконання роботодавцем зобов'язання щодо працевлаштування не є класичною позовною вимогою про захист права в розумінні КЗпП України, однак може бути визначена позивачем як вимога про застосування судом ефективного способу захисту порушеного приватного права, оскільки не суперечить закону (ч. 2 ст. 232 КЗпП України).

Важливою ремаркою тут буде твердження про те, що позивач не вправі залишати пред'явлену до суду вимогу «відкритою», тобто просити суд визначити ефективний спосіб захисту порушеного, невизнаного або оспореного приватного права та інтересу, який не суперечить закону, не зазначивши такої у змісті своїх позовних вимог, як конкретно сформульованої відповідно до змісту порушеного права, що забезпечує його реальне поновлення. Інакше, на нашу думку, суддям слід залишати такі позовні заяви без руху з підстав, передбачених ч. 1 ст. 185 ЦПК України. Так, Верховний Суд у Постанові від 22 листопада 2019 року погодився із судами, установивши, що позивач не усунув недоліки позовної заяви, зазначені в ухвалі районного суду від 18 січня 2018 року, а саме не уточнив прохальну частину позовної заяви відповідно до вимог п. 4 ч. 3 ст. 175 ЦПК України, не визначив зміст позовних вимог щодо кожного зі співвідповідачів та не конкретизував, яким саме способом просить захистити його права; суд першої інстанції, з яким погодився суд апеляційної інстанції, дійшов правильного висновку про визнання уточненої позовної заяви від 17 січня 2018 року неподаною та повернення їі заявнику [5].

У справі № 757/77004/17-ц позивачка, використовуючи новелу, разом з основною вимогою залишила пред’явлену до суду вимогу «відкритою», сформулювавши ії загально, передавши ініціативу суду. Так, посилаючись на порушення відповідачем законодавства України у сфері житловокомунальних послуг та захисту прав споживачів, позивачка просила суд визнати укладеним договір про надання послуг 3 централізованого постачання холодної води та водовідведення між сторонами у справі у редакції, викладеній позивачкою, або захистити права, свободи та інтереси позивачки із застосуванням іншого способу захисту, який не суперечить закону, є ефективним і який суд вважає за доцільне та/або можливе застосувати. За наслідками розгляду справи суди відмовили у задоволенні вимог за їх безпідставністю [6].

Іншим прикладом некоректного формулювання вимог є справа № 369/9266/18. Колегія суддів Київського апеляційного суду погодилась із тим, що нарахування відповідачем заборгованості $є$ перешкодою для оформлення субсидії, проте для вирішення позовних вимог у спосіб, вибраний позивачем, останній мав надати докази на спростування такої заборгованості, але таких доказів подано не було. Оскільки у позовній заяві позивач не зазначив ні період, за який він вважає неправильно нарахованим борг, ні суму самого боргу, ні кількість спожитої електроенергії, ні суму, яку він просить стягнути 3 відповідача як надмірно сплачену, вибір судом іншого способу захисту у порядку ч. 2 ст. 5 ЦПК України є неможливим [7].

Отже, за системним аналізом ч. 2 ст. 5 , ч. 1 ст. 13 , п. 4 ч. 3 ст. 175 , ч. 2 ст. 264 ЦПК України можна дійти висновку, що вимога про застосування судом ефективного способу захисту порушеного, невизнаного або оспореного приватного права та інтересу, який не суперечить закону, має бути викладена у позовній заяві, а саме має бути відображена (конкретно сформульована) у змісті позовних вимог, саме це є первинною підставою для застосування судом новели. Інакше суд позбавляється процесуальної можливості застосувати новелу цивільного процесуального права та визначити ефективний спосіб захисту порушеного, невизнаного або оспореного приватного права та інтересу, який не суперечить закону.

2) Предмет та підстави позову визначаються тільки позивачем, тоді як суд позбавлений права на відповідну процесуальну ініціативу.

Однією з умов правильного, на наш погляд, застосування судом новели є неухильне дотримання одного з основних принципів цивільного судочинства, а саме принципу диспозитивності, під час визначення підстав та предмета позову, оскільки останні процесуальні категорії є тісно пов'язаними з ефективним способом захисту.

Диспозитивність, як вважає В.Л. Яроцький, перш за все полягає у визначеній 
нормами цивільного права можливості управомочених осіб діяти ініціативно, вибираючи можливі варіанти їх правомірної поведінки, тобто самостійно визначати форми реалізації комплексу наданих їм правових можливостей. Інші автори також зазначають, що характерними рисами диспозитивного уповноважувального елемента цивільно-правового методу є, окрім іншого, можливість вибору учасниками цивільних відносин варіанта поведінки, що не суперечить засадам цивільного законодавства й нормам моралі. Учасники цивільних правовідносин самостійно вибирають форми, способи, час і межі своєі юридичної та фактичної поведінки, не порушуючи прав інших, сторонніх осіб. У цьому знаходить свій вияв загальна ідея, згідно з якою в галузі приватного права особа здійснює свої суб'єктивні права вільно, на власний розсуд [8, с. 30-31].

Досліджуючи вільність розсуду, Т.М. Підлубна зазначала, що, згідно зі ст. 20 ЦК, право на захист особа здійснює на власний розсуд. Через цю норму закону реалізується один 3 основних принципів цивільного права, а саме принцип свободи вибору поведінки особи під час реалізації свого права на захист. Особа вільна у виборі механізму здійснення свого права на захист, а також у змозі відмовитися від реалізації цього права. Це свідчить про те, що особа вільна у застосуванні будьяких способів захисту, які передбачені чинним законодавством. Однак перш ніж застосувати той чи інший спосіб захисту, особа, права якої порушено, невизнано чи оспорено, постає перед проблемою вибору того чи іншого способу захисту, який оптимально забезпечить відновлення іï̈ порушеного права [9, с. 41-42].

У контексті визначення процесуальних ініціатив Верховний Суд у Постанові від 19 червня 2019 року зазначив таке. Учасник справи розпоряджається своїми правами щодо предмета спору на власний розсуд. Таке право мають також особи, в інтересах яких заявлено вимоги, за винятком тих осіб, які не мають процесуальної дієздатності. Під предметом позову розуміється певна матеріально-правова вимога позивача до відповідача, стосовно якої позивач просить прийняти судове рішення. Підставу позову становлять обставини, якими позивач обгрунтовує свої вимоги щодо захисту права та охоронюваного законом інтересу. Відтак зміна предмета позову означає зміну вимоги, з якою позивач звернувся до відповідача, а зміна підстав позову - це зміна обставин, на яких грунтується вимога позивача. Попри обов'язок суду вирішити наявний між сторонами спір задля ефективного захисту порушених, невизнаних або оспорюваних прав і законних інтересів відповідних осіб, предмет та підстави позову визначаються та можуть в установленому порядку змінюватися тільки позивачем, тоді як суд позбавлений права на відповідну процесуальну ініціативу [10].

Верховний Суд у складі колегії суддів Третьої судової палати Касаційного цивільного суду у Постанові від 5 грудня 2019 року зазначив, що принцип диспозитивності у цивільному судочинстві реалізується шляхом вільного розпорядження такими процесуальними правами, які, зокрема, впливають на виникнення, рух, розвиток і закінчення судового розгляду (право на звернення з позовом, право на зміну предмета або підстав позову), випливають з участі у розгляді справи, забезпечують сторонам належний судовий захист [11].

Наведений висновок підтверджується також чинними положеннями ч. 3 ст. 49 ЦПК України про те, що позивач має право змінити предмет або підстави позову шляхом подання письмової заяви до закінчення підготовчого засідання.

Принцип диспозитивності, реалізований під час здійснення суб'єктивних прав, рівною мірою може бути застосований також до вибору способу захисту, а це означає можливість вибору заінтересованою особою способу захисту на іï̈ власний розсуд. Подібні твердження можуть викликати ілюзію можливості використання для захисту порушеного права будь-якого з наявних способів захисту, що насправді не відповідає дійсності [9, c. 41-42].

Велика Палата Верховного Суду у Постанові від 17 квітня 2018 року висловила правові висновки, у яких чітко розмежовує правомочності носіїв суб'єктивних прав та суду. Визначення відповідачів, предмета та підстав спору є правом позивача. Натомість установлення належності відповідачів і обгрунтованості позову є обов'язком суду, який виконується під час розгляду справи [12].

Отже, визначення предмета та підстави позову є виключним вольовим правом позивача - носія порушеного, невизнаного, оспореного суб'єктивного права; суд позбавлений права на відповідну процесуальну ініціативу, зокрема, в разі визначення ефективного способу захисту порушеного, невизнаного або оспореного приватного права та інтересу.

3) Необхідність належного правового обгрунтування вимог відповідними нормами матеріального права та самостійне застосування таких норм судом за принципом јura novit curia.

У науці та судовій практиці вже давно точиться дискусія щодо того, чи 
є обов'язковою умовою під час захисту прав та інтересів правильне обгрунтування нормами матеріального права визначеного в позові предмета та відповідного ефективного способу захисту права, а також чи не буде підставою для відмови у задоволенні позову виключно помилкове зазначення позивачем норми матеріального права за умови правильно визначеного й ефективного способу захисту права чи інтересу.

Оскільки поставлені вище питання $€$ надто важливими в контексті визначення умов застосування процесуальної новели, варто проілюструвати таку судову справу. На думку Верховного Суду у складі палати для розгляду справ щодо земельних відносин та права власності Касаційного господарського суду, процесуально-правовий аспект захисту права включає не лише правильність вибору передбаченого законом або договором способу захисту, але й необхідність належного правового обгрунтування вимог відповідними нормами права [13].

Так, Верховний Суд в ухвалі від 23 вересня 2019 року, обгрунтовуючи передачу справи до Великої Палати Верховного Суду, зазначив, що визначення способу захисту, а саме визначення позовних вимог, обгрунтування позову певними правовими нормами, як і посилання на фактичні обставини справи та визначення предмета спору, процесуальним законом покладено саме на позивача, у зв'язку з чим у відповідача у справі виникають певні правомірні очікування, оскільки реалізація його прав на захист проти позову перебуває у прямому причинно-наслідковому зв'язку 3 правовими вимогами та підставами, викладеними саме позивачем. Виходячи з аксіоми цивільного судочинства jura novit curia («суд знає закон»), під час розгляду справи суд дійсно повинен надати правильну правову кваліфікацію відносинам сторін, яка, проте, не може бути застосована судом для вирішення спору по суті за відсутності відповідних позовних вимог позивача у справі, оскільки інший підхід суду порушив би принцип диспозитивності судового процесу та правомірні очікування як позивача (який звертається саме 3 певним чином обгрунтованою в правовому аспекті вимогою), так і відповідача (який, виступаючи проти позову, наводить доводи саме щодо тих підстав та обгрунтувань, які наводяться позивачем у справі) [13].

Велика Палата Верховного Суду у Постанові від 4 грудня 2019 року із зазначеними вище висновками не погодилась та сформулювала у наведеній справі такі правові висновки. До моменту оформлення власником об'єкта нерухомого майна права оренди земельної ділянки, на якій розташований цей об'єкт, відносини з фактичного користування земельною ділянкою без укладеного договору оренди та недоотримання її власником доходів у вигляді орендної плати є за своїм змістом кондикційними. Спірні правовідносини судами кваліфіковані помилково як такі, що виникли із завданням збитків у зв'язку з використанням земельної ділянки без правовстановлюючих документів. Підстави позову - це зазначена в позовній заяві нормативно-правова кваліфікація обставин, якими позивач обгрунтовує свої вимоги. При цьому незгода суду з наведеним у позовній заяві правовим обгрунтуванням щодо спірних правовідносин не є підставою для відмови у позові, як помилково вважали суди попередніх інстанцій у цій справі. Оскільки повноваження органів влади, зокрема щодо здійснення захисту законних інтересів держави, є законодавчо визначеними, суд, згідно з принципом jura novit curia («суд знає закони»), під час розгляду справи має самостійно перевірити доводи сторін щодо безоплатного користування земельною ділянкою та відшкодування коштів, пов'язаних з її використанням, без належного оформлення правовстановлюючих документів на неї. Суди, з'ясувавши під час розгляду справи, що сторона або інший учасник судового процесу на обгрунтування своїх вимог або заперечень послався не на ті норми права, що фактично регулюють спірні правовідносини, самостійно здійснює правильну правову кваліфікацію останніх та застосовує для прийняття рішення ті норми матеріального й процесуального права, предметом регулювання яких $€$ відповідні правовідносини. Зазначення позивачем конкретної правової норми на обгрунтування позову не є визначальним під час вирішення судом питання про те, яким законом слід керуватися під час вирішення спору. Велика Палата Верховного Суду зазначає, що саме на суд покладено обов'язок надати правову кваліфікацію відносинам сторін $з$ огляду на факти, встановлені під час розгляду справи, та визначити, яка правова норма підлягає застосуванню для вирішення спору. Самостійне застосування судом для прийняття рішення саме тих норм матеріального права, предметом регулювання яких $€$ відповідні правовідносини, не приводить до зміни предмета позову та/або вибраного позивачем способу захисту [14].

Зазначений правовий висновок Великої Палати Верховного Суду заслуговує на підтримку в контексті основного завдання цивільного судочинства, яке полягає у здійсненні ефективного захисту прав під час вирішення справ, однак слід зазначити, що 
під час його впровадження на практиці може ще більше поглибитися проблема низького рівня правової свідомості під час підготовки та обгрунтування позовних заяв. Слід зазначити, що у наведеній вище справі № 917/1739/17 предметом судового розгляду була конкуренція лише двох способів захисту, а саме відшкодування збитків (ст. ст. 22, 1166 ЦК) та стягнення коштів, збережених без достатньої правової підстави (ст. 1214 ЦК) [14]. Інакше, коли у позовах наводиться палітра способів захисту, що $€$ взаємовиключними та без належного правового обгрунтування їх відповідними нормами матеріального права, суд має вирішити спір, застосувавши ті норми, що відповідають спірним правовідносинам. Надмірна хаотичність правового обгрунтування позовних вимог, з одного боку, ускладнює сторонам їх завдання, що покладаються на них за принципом змагальності, а саме доведення кожної підстави та обгрунтування своїх вимог або заперечень, з іншого боку, ускладнюе завдання суду, завантаживши його додатковими функціями з перевірки на відповідність закону кожної вимоги та її правового обгрунтування. Зрештою, на нашу думку, за умови встановлення наведеної вище надмірної хаотичності правового обгрунтування позовних вимог у конкретній судовій справі Велика Палата Верховного Суду зможе відступити від наведеного вище висновку задля підвищення правової дисципліни захисту прав під час звернення до суду та пристане на позицію Касаційного господарського суду щодо необхідності належного правового обгрунтування вимог відповідними нормами права.

Отже, суд за принципом jura novit curia («суд знає закони») самостійно здійснює правову кваліфікацію спірних правовідносин та застосовує для прийняття рішення саме ті норми матеріального права, предметом регулювання яких є відповідні правовідносини, що не приводить до зміни предмета позову та/або вибраного позивачем способу захисту. При цьому вимоги про застосування судом ефективного способу захисту порушеного, невизнаного або оспореного приватного права та інтересу, який не суперечить закону, насамперед будуть оцінюватися судом щодо відповідності його предмету й підставам позову. У подальшому такі вимоги будуть самостійно перевірені судом на відповідність правовідносинам, що виникають між сторонами у конкретних справах, та праву, що його регулює, а належне правове обгрунтування позовних вимог відповідними нормами матеріального права не буде визначальним під час ухвалення рішення. Іншими словами, якщо позивач неправильно в контексті матеріального права обгрунтує свої позовні вимоги, однак визначений ним предмет позову та вибраний спосіб захисту будуть близькими та однорідними за наслідками їх виконання (наприклад, стягнення грошових коштів, повернення майна) під час застосування різних норм матеріального права, це не приведе до відмови у задоволенні позову.

\section{Висновки}

Вимога про застосування судом ефективного способу захисту порушеного, невизнаного або оспореного приватного права та інтересу, який не суперечить закону, має бути викладена в позовній заяві, а саме має бути відображена (конкретно сформульована) у змісті позовних вимог, і саме це є первинною підставою для застосування судом новели.

Визначення предмета та підстави позову $є$ виключним вольовим правом позивача носія порушеного, невизнаного, оспореного суб'єктивного права, суд позбавлений права на відповідну процесуальну ініціативу, зокрема щодо визначення ефективного способу захисту порушеного, невизнаного або оспореного приватного права та інтересу, який суперечить закону.

Суд за принципом jura novit curia («суд знає закони») самостійно здійснює правову кваліфікацію спірних правовідносин та застосовує для прийняття рішення саме ті норми матеріального права, предметом регулювання яких є відповідні правовідносини, що не приводить до зміни предмета позову та/або вибраного позивачем способу захисту. Помилкове посилання на норму матеріального права для обгрунтування предмета позову та/або вибраного позивачем способу захисту не буде визначальним під час вирішення спору судом.

3 огляду на викладене можна дійти висновків, що наведені підстави формування вимоги ефективного захисту приватного права та інтересу є обов'язковими, складають основоположні засади застосування новели, тому мають враховуватися сторонами цивільного процесу та судом під час складання процесуальних документів у цивільному процесі.

\section{Список використаних джерел:}

1. Барак А. Судейское усмотрение / пер. с англ. Москва : Норма, 1999. 376 с.

2. Про внесення змін до Господарського процесуального кодексу України, Цивільного процесуального кодексу України, Кодексу адміністративного судочинства України та інших законодавчих актів : Закон України від 3 жовтня 
2017 року №2147-VIII. URL: https://zakon.rada.gov. ua/laws/show/2147-19 (дата звернення: 26.02.2020).

3. Печений О.П., Спасибо-Фатєєва I.В. та ін. Захист права власності. Правові позиції Верховного Суду: коментарі науковців. Харків : ЕКУС, 2020. $496 \mathrm{c}$.

4. Постанова Великої Палати Верховного Суду від 16 травня 2018 року у справі № 759/19440/15ц. URL: http://www.reyestr.court.gov.ua/ Review/74120972 (дата звернення: 26.02.2020).

5. Постанова Верховного Суду від 22 листопада 2019 року у справі № 639/4913/15-ц- URL: http://reyestr.court.gov.ua/Review/86000368 (дата звернення: 26.02.2020).

6. Постанова Київського апеляційного суду від 22 квітня 2019 року у справі № 757/77004/17-ц. URL: http://reyestr.court.gov. ua/Review/81392688 (дата звернення: 26.02.2020).

7. Постанова Київського апеляційного суду від 21 травня 2019 року у справі № 369/9266/18. URL: http://reyestr.court.gov.ua/ Review/81907135 (дата звернення: 26.02.2020).

8. Кот О.О. Здійснення та захист суб'єктивних цивільних прав: проблеми теорії та судової практики : монографія. Київ : Алерта, 2017. $494 \mathrm{c}$.
9. Підлубна Т.М. Критерії вибору способу захисту суб'єктивних цивільних прав та інтересів. Науковий вісник Чернівецького університету. 2008. Вип. 435 : Правознавство. С. 40-42.

10. Постанова Верховного Суду від 19 червня 2019 року у справі № 910/19581/16-ц. URL: http://reyestr.court.gov.ua/Review/82599569 (дата звернення: 26.02.2020).

11. Постанова Верховного Суду від 5 грудня 2019 року у справі № 705/3869/18. URL: http:// reyestr.court.gov.ua/Review/86241370 (дата звернення: 26.02.2020).

12. Постанова Великої Палати Верховного Суду від 17 квітня 2018 року у справі № 523/9076/16-ц. URL: http://reyestr.court.gov. ua/Review/73469613 (дата звернення: 26.02.2020).

13. Постанова Верховного Суду у складі палати для розгляду справ щодо земельних відносин та права власності Касаційного господарського суду від 23 вересня 2019 року у справі № 917/1739/17. URL: http://reyestr.court.gov.ua/ Review/84454017 (дата звернення: 26.02.2020).

14. Постанова Великої Палати Верховного Суду від 4 грудня 2019 року у справі № 917/1739/17. URL: http://reyestr.court.gov.ua/ Review/86310237 (дата звернення: 26.02.2020)

The article is devoted to the research and analysis of the requirement of effective protection of private law and interest in procedural documents from the standpoint of the parties to civil proceedings as a novelty of civil procedural legislation. It has been proved that in order to prevent unequal interpretation of the law, to predict possible errors in the application by the parties of the civil process and the courts, there is a scientific and practical need to develop common approaches to the formation of the requirement of effective protection of law in procedural documents. The rights and obligations of the parties to the civil proceedings are justified by the separate grounds for forming the requirement of effective protection of the law in the procedural documents as obligatory for the correct determination by the court of an effective method of protection which is not contrary to the law, the bases are formed on the basis of existing scientific relatives on the subject of regulation of legal categories concerning the researched novel, and also on the basis of the analysis of practice of national courts. It is proved that the requirement for the court to apply an effective way of protecting the violated, unrecognized or disputed private law and interest, which is not contrary to the law, should be stated in the statement of claim, and it should be reflected in the content of the claims. It is substantiated that the determination of the subject matter and the basis of the claim is the exclusive will of the plaintiff, the court is deprived of the right to appropriate procedural initiative.

Key words: requirement of effective protection of the infringed, unrecognized or contested right, determination by the court of an effective method of protection, method of protection which is not contrary to the law, effective remedy, procedural initiative. 